\title{
The Limitation and Development of Elizabeth Gaskell’s Social Vision
}

\author{
Yinghuei Chen \\ Department of Foreign Languages \& Literature, Asia University, Taichung, Taiwan
}

\begin{abstract}
Gaskell, for all her sympathy for the lower orders, responds to questions posed by differences of class with a conciliatory spirit. She writes like a social realist, but when she is confronted with taking a position, she often opts for reconciliation or even escapism. Gaskell's ambivalent attitude towards social classes is brought to the forefront in Mary Barton (1847), which she originally entitled John Barton. The change of the title has led to critical argument that the novel is an artistic failure, and the shift from a political novel with a clear social purpose to a domestic romance which covers up social discontent is too unprepared and comes across as a fantasy on the part of the novelist. This peculiar structure of the novel reveals the limitation of Gaskell's social vision as a novelist. In North and South (1852), Gaskell presents the precarious situation of workers and their tense relations with industrialists in a more balanced way by giving more attention to the thinking and perspective of the employers, a narrative perspective far different from her treatment in Mary Barton which adopts the view of the working poor. The on-going social mobility and the shift of social gravity from the aristocracy to the mercantile, a historical reality which Matthew Arnold clearly delineates in Culture and Anarchy, are truthfully observed and represented by Gaskell and her representation of this new ruler class marks her progressive social view, expressing her optimistic belief in England's progress towards an industrial future. In an interval of seven years between the publications of the two novels in question, Gaskell’s social vision had matured into critical realism.
\end{abstract}

Keywords: social realist, social purpose, political novel, domestic romance, progressive social view, critical realism

\section{Introduction}

Are writers in their literary production and social ideology determined and confined by their social life and the class they originate from? Can they transcend their material conditions? This paper aims to answer these intriguing questions by using Elizabeth Gaskell as a point of departure while exploring the correspondence between literary creation and social life, a relationship which the French critic Lucien Goldmann cogently argues in his book entitled Towards a Sociology of the Novel. ${ }^{1}$ Gaskell's two industrial novels, Mary Barton and North and South and the progressive view of her social vision, as tellingly revealed by the two novels in question, will be investigated for this purpose.

\section{Elizabeth Gaskell, a Prominent yet Lesser Writer}

Elizabeth Gaskell, Mrs. Gaskell in many editions of her work, falls into the category of great yet eclipsed,

Yinghuei Chen, Dean, Professor, Department of Foreign Languages \& Literature, College of Humanities and Social Sciences, Asia University.

${ }^{1}$ Lucien Goldmann, Towards a Sociology of the Novel, Alan Sheridan (Trans.), London: Tavistock, 1975. 
a comprehensive subsection of the great writers of her time. Like Marlowe overshadowed by Shakespeare, or Dean by Frank, ${ }^{2}$ Gaskell was particularly unfortunate because she had to labor under the overshadowing popularity of her contemporary Dickens, ${ }^{3}$ a writer whose suavity, charm, and sheer productivity overwhelms all those around him. Indeed the list of unfortunate contenders continues but, once one is numbered within it, redemption comes hard and much is lost along the way with the contraction of themes and abridgement of the works to fit the established notion of "the lesser." While Dickens is an institution and his work forms the basis of our common conception of how Victorian life was lived, Gaskell seems a square peg, lacking a clearly defined position within the 19th century literary tradition. Even the use of her married title in her bylines seems condescending and compartmentalizing — bracketing her as someone's wife, which essentially conveys overtones of an adjunct and colors our perceptions of her work before we have opened any of her books.

It seems futile and pointless to try to gauge Gaskell's status in a literary world absent of Dickens; we should instead compare them in their approach to a common subject, for both contribute to the subgenre of the industrial novel. ${ }^{4}$ Gaskell deals with this in Mary Barton (1848) and North and South (1855) while Dickens touches upon the subject mainly in Hard Times (1854), a novel that comes after Gaskell's first novel by six years, though many of his earlier works often more or less allude to this issue. In truthful presentation of life struggling under industrial conditions, Gaskell is obviously Dickens's forerunner, and her contribution to the development of this literary tradition can be considered significant, with her particular attention to and faithful representation of the realities of working class life.

\section{Gaskell and Unitarian Connections}

Gaskell, like many of her contemporaries, wrote with a clear social purpose-to improve the lot of the working poor or at least to draw attention to it-a humanitarian concern and social consciousness which perhaps derived from her family upbringing and her espousal to an eminent Unitarian minister at a local chapel in Manchester. ${ }^{5}$ Gaskell's father, William Stevenson, and her husband, William Gaskell, were both Unitarian ministers, a sect which urges, among many things, tolerance towards all religions, support for charity work and opposition to the slave trade, all common themes which permeate her works. Gaskell, as a result of her family connection and her duty as a minister's wife, had opportunities to visit the homes of millworkers and to thereby learn about life among the poor. Through these contacts she had at least a degree of first-hand knowledge of what was ailing a burgeoning industrialized city like Manchester. She also became acquainted with all the social problems of industrialization, in particular the tension between employers and workers, the gap between rich and poor, trade unionization and the social unrest that the Chartist Movement generated. ${ }^{6}$

As befitted the wife of a Unitarian clergyman, Gaskell took it upon herself to launch relief work and promote the wellbeing of manual laborers and mill workers. After her marriage she lived in Manchester, the

\footnotetext{
2 Dean Martin (1917-1995) was an American singer, film actor, television star and comedian, one of the most popular and enduring American entertainers in the mid-20th century; Francis Albert "Frank" Sinatra (1915-1998) was an American singer and film actor who became an unprecedentedly successful solo artist from the early to mid-1940s, after being signed to Columbia Records in 1943.

${ }^{3}$ Gaskell wrote stories and novels for Charles Dickens; North and South, for example, appeared in 20 weekly serials from September 1854 to January 1855 in Household Words, edited by Dickens.

4 For a discussion of the industrial novels, see Raymond Williams' chapter in Culture and Society: 1780-1950 (London: Hogarth, 1982), pp. 87-109.

${ }^{5}$ See Winifred Gérin, Elizabeth Gaskell: A Biography (Oxford: Oxford UP, 1980), chs. I \& IV.

${ }^{6}$ A movement for extension of political power to the working classes caused by the passing of the Reform Bill (1832). The following riots led to the movement's suppression in 1848.
} 
setting for Mary Barton, and saw there in person the suffering resulting from the mass migration of the rural population in search of work in the mills. She also witnessed how poor people in their struggle for life sank into poverty and misery, the overwhelming social realities of the Victorian Era that Friedrich Engles vividly recorded in The Condition of the Working Class in England (1845). ${ }^{7}$ Gaskell was pricked by her social conscience to speak for these people, ${ }^{8}$ and her stand marked the kind of social mission that many writers of the Victorian period partook of to gain public attention to the social doctrines they cherished.

\section{“Condition of England Question”}

North and South (1855), considered a tour de force in the exploration of what Thomas Carlyle calls in Past and Present (1843) the "Condition of England Question", was set in the fictional town of Milton, North of England, where industrialization was altering the contour of the city. The novel focuses, among many things, on the confrontation between John Thornton, representative of the north, who is an emerging capitalist in the wake of the Industrial Revolution, and Margaret Hale, supposedly a southerner, who is forced to leave her home in the tranquil rural south and settle with her parents in the industrial town where she witnesses a harsh brutal world wrought by industrialization and its concommitant doctrine of the laissez faire. Their confrontation, reminiscent to some degree of Elizabeth Bennet and Mr. Darcy in Jane Austen's Pride and Prejudice, ${ }^{10}$ however, is set in the broad context of the harsh industrial North. Margaret and Thornton, it seems, treat the laborers differently; while the girl, despite being "haughty", is sympathetic to the poor workers and befriends them. Thornton, a firm adherent of the laissez faire, only shows contempt for them. But unlike Gaskell's earlier treatment in Mary Barton whose narrative adopts the view of the working poor, in North and South she presents the precarious situation of workers and their tense relations with industrialists in a more balanced way by giving more attention to the thinking and perspective of the employers, ${ }^{11}$ a point to be further expounded later when it comes to the discussion of the class issue in the novel.

\section{Gaskell and Her Social Vision}

Like Dickens in his abhorrence to revolution, Gaskell, for all her sympathy for the lower orders, responds to questions posed by differences of class with a conciliatory spirit. In other words, she writes like a social realist, but when she is confronted with taking a position, she opts for reconciliation or escapism. In North and

\footnotetext{
7 The book was first published in German in Leipzig in 1845 and its English edition (authorized by Engels) was published in 1887 in New York and in London 1891.

${ }^{8}$ See Elizabeth Gaskell's “Preface” of Mary Barton, edited and introduced by Shirley Foster (Oxford: Oxford UP, 2006), pp. 3-4. Hereafter any quotations from the novel refer to this edition.

${ }^{9}$ Carlyle first used the phrase "Condition of England Question" in Chartism (1839), which significantly contributed to the emergence of a series of debates about the spiritual and material foundations of England and it had a great effect on a number of writers of fiction in the Victorian era and after. Carlyle continued to address the same issue in Past and Present (1843), observing "The condition of England, on which many pamphlets are now in the course of publication, and many thoughts unpublished are going on in every reflective head, is justly regarded as one of the most ominous, and withal one of the strangest, ever seen in this world" (p. 7).

See Thomas Carlyle, Past and Present, Richard D. Altick (Ed.) (New York: New York UP, 1965). Evidence of Carlyle’s influence on Gaskell can be seen, for example, in her allusion to "Biography" in Fraser's Magazine, 5 (Apr. 1832) in the title page of Mary Barton.

10 Janine Barchas (2008), “Mrs. Gaskell's North and South: Austen’s early legacy” in Persuasions, The Jane Austen Journal, 30, 53-66.

${ }^{11}$ Elizabeth Gaskell, Mary Barton/North and South, Alison Chapman (Ed.) (Duxford: Icon Books, 1999), p. 26. See also Patricia Ingham, Introduction to North and South, Penguin Classics (Harmondsworth: Penguin, 1995), pp. xii-xiii, and Martin Dodsworth, Introduction to North and South, ed. Dorothy Collin (Harmondsworth: Penguin, 1970), p. 17. Hereafter any quotations from the novel refer to Collin's edition.
} 
South, as so often happens in Jane Austen, resolution is achieved through the magic wand of marriage, in this instance of Margaret and Thornton. This resorts to marriage as a social panacea whereby the issue of social mobility is resolved or at least prorogued places Gaskell in the less radical party. As Raymond Williams well observes in his discussion of the novel, "The relationship of Margaret and Thornton and their eventual marriage serve as a unification of the practical energy of the Northern manufacturer with the developed sensibility of the Southern girl."12 The social function of marriage as a means of class resolution is reasserted.

Gaskell in this light is often deemed conservative in her attitude toward social change, and her conservatism goes even further to endorse avuncularism in the treatment of the working classes. Thornton, the capitalist in the end, realizes the value of mutual understanding and the love that exists between masters and men, a Christian spirit well voiced by the philosophic laborer Job Legh in Mary Barton. ${ }^{13}$ Thornton also understands that the ultimate solution to class tension is the incumbent responsibility of the employers for their employees, very much the concept of paternalism which is highly promoted by John Ruskin in his writings. ${ }^{14}$

Gaskell's seemingly ambivalent attitude towards social classes is brought to the forefront in her first novel Mary Barton, which she originally entitled John Barton. The change of the title from John Barton, the father whom Gaskell said was the "the central figure to my mind. ...he was my 'hero." "15 to Mary Barton, the daughter, has caused quite a few critics to argue that the novel in this regard is an artistic failure, and the shift from a political novel with a clear social purpose to a domestic romance which covers up social discontent is too abrupt and comes across as a fantasy on the part of the novelist. Raymond Williams, for one, attacked this compositional disrupture, seeing this shift of focus as a failure by the author. The early chapters of the book, he observed, are the "most moving response in literature to the industrial suffering of the 1840s," but later the novel becomes a "familiar and orthodox. ...Victorian novel of sentiment". ${ }^{16}$ This disruption or discontinuity in the flow of narrative tellingly reveals Gaskell's real position in regard to political upheaval, an artistic gesture which calls attention to the intriguing question of the correspondence between literary creation and social life, a relationship which the French critic Lucien Goldmann cogently argues in his book entitled Towards a Sociology of the Novel. ${ }^{17}$ Are writers in their literary production and social ideology determined and confined by their social life and the class they originate from? Can they transcend their material conditions? D. H. Lawrence seems to endorse this idea in his "Study of Thomas Hardy"18 when he attacks Hardy for his "petty bourgeoisie” ideology because all the rebels in Hardy's novels, protagonists such as Tess or Jude who dare to reject social mores and conventions are all killed off at the end, although he fails to recognize the validity of these results when faced with the repression of working class aspirations by the establishment. This may seem rather palimpsestic leaving out too many factors which may have exerted themselves upon the construction of a novel. Lawrence's criticism of Hardy, however, derives from his belief that art is produced not in a vacuum but in close correspondence to a writer's social milieu, certainly Goldmann’s perspective.

12 Culture and Society, p. 92.

13 See Mary Barton, Ch. xxxvii, pp. 370-373.

14 See, for example, Peter O’Neill (2001). A World of Deference: Paradoxes of Victorian Paternalism in John Ruskin, Charles Dickens, and John Stuart Mill. Louisiana State University.

15 Cited in Culture and Society, p. 88.

16 Culture and Society, p. 89.

17 Lucien Goldmann, Towards a Sociology of the Novel, Alan Sheridan (Trans.), London: Tavistock, 1975.

18 D. H. Lawrence, Study of Thomas Hardy and Other Essays (The Cambridge Edition of the Works of D. H. Lawrence), Bruce Steele (Ed.), (Cambridge: Cambridge UP, 1985). 


\section{Mary Barton}

Gaskell is then humanitarian in her rendition of the lower orders with which she has always "felt a deep sympathy" but lands herself in a dilemma where she is forced to confront her position as a writer. As she frankly and unhesitatingly observes again in her Preface to Mary Barton, the suffering she saw around her was the motivational factor that prompted her to write:

I had always felt a deep sympathy with the care-worn men, who looked as if doomed to struggle through their lives in strange alternations between work and want [...] The more I reflected on this unhappy state of things between those so bound to each other by common interests, as the employers and the employed must ever be, the more anxious I became to give some utterance to the agony which from time to time convulsed this dumb people. ${ }^{19}$

Sympathetic as she was to the poor and the suffering, she had to forsake John Barton in the middle of her composition when he, the declared chartist, committed the crime of killing Harry Carson, heir to a wealthy mill owner. The murderer is abandoned after resorting to physical violence in opposition to social injustice. This withdrawal of sympathy and subsequent shift of focus exemplifies Gaskell's fear, or even horror of the unleashed forces of social discontent which further reflects her divided loyalty where class issues are concerned. Two opposing consciousnesses are at odds here concerning the dominant bourgeoisie and the emergent working classes, whose potential conflicts Mathew Arnold clearly delineates in Culture and Anarchy (1869). ${ }^{20}$ Gaskell's support for the working laborers must surely derive from humanitarianism, but when mob violence becomes a social reality, she resorts to her class perspective by condemning chaos and turbulence. Her rejection of any social unrest that might lead to anarchy is instinctive as it was strongly associated with the French Revolution and that event's descent into horror. This give-and-take attitude constitutes Gaskell's salient "structure of feeling" as a writer, a contradiction complex, we may call it, which exacts its effect on the novel's change of focus.

As the novel unfolds and develops, John, the ardent supporter of the Chartist Movement (1837-1848), is found actively engaged in petitioning for the working poor by joining the trade union movement. Through the meticulous portrayal of John and his living conditions Gaskell intends to offer a detailed and faithful record of the laborers' life in Manchester in the 1840s with a realistic and critical perspective, "to give some utterance to the agony which from time to time convulses this dumb people,"21 a realism, it must be added, lacking in North and South. As we have mentioned above, however, at the story's halfway point, the novelist changes her narrative perspective. Her descriptions of the miserable conditions and bitter feelings of the laborers are abandoned and replaced by the romance of Mary and Jem Wilson. This surprisingly total redirection, as we have previously observed, was occasioned by John's crime, committed after his several failed attempts on behalf of the union to appeal to his employer for social redress. It is then and at this point of the story that Gaskell recuses herself from tangible social reality, and the whole novel consequently seems to fall apart, becoming two completely different texts. The earlier section of the book is written in a realistic mode, truthfully representing the social ills that we often encounter in an industrial novel, although it seems the picturesque or carnival is never far away, say, in Dickens' Hard Times or Disraeli's Sybil (1845), whereas the

${ }^{19}$ See Gaskell's “Preface” of Mary Barton in Foster's edition, p. 3.

20 Culture and Anarchy is a series of essays by Matthew Arnold, first published in Cornhill Magazine 1867-1868 and collected as a book in 1869. The preface was added in 1875. See Robert H. Super, Culture and Anarchy with Friendship's Garland and Some Literary Essays, Volume V of The Complete Works of Matthew Arnold, The University of Michigan Press, 1965.

${ }^{21}$ See Gaskell’s “Preface” of Mary Barton in Foster's edition, p. 3. 
second half is written in the manner of domestic romance, the kind of love story that George Eliot condemned as "silly novels" by the novelists of her own sex. ${ }^{22}$ This peculiar structure of the novel reveals the limitation of Gaskell's social conscience as a writer and the inner contradiction she confronts as a novelist; its commercial success, however, suggests either she or her publisher knew what sold.

Furthermore, the ending of the novel comes as a deus ex machina, a convenient ploy to send off stage the characters for whom the author feels sympathy while finding herself unable to resolve their social problems. Mary and Jem Wilson choose to leave for Canada to start a new life there, a choice made available to them because of the reach of the British Empire. Indeed, from the perspective of a postcolonial discourse, the act of emigration is in itself an imperial act, conferring populations on conquered regions, and Gaskell, like many writers of her time, was well aware of these colonial activities. She is merely making good use of her imperialist fantasy to send away from Britain what Thomas Malthus liked to call the "redundant population.,23 This, too, is the very means with which Charles Dickens dispenses with the socially unwanted, the misfits, and those beyond the redemptive pale of the British Isles. This ending, though comforting and problem-solving in its own way, could be viewed as an escapist strategy, ${ }^{24}$ and Gaskell in this sense is herself an escapist, for the conflict between the employer and the employed continues unabated and unresolved for all this and any real solution to the social ills that the novel has dramatized throughout the book are not addressed.

Gaskell is often regarded as a Christian humanist and the two industrial novels we have discussed above are devoted to expressing her humanitarian spirit. She partook of the responsibility for social reform and subsequent advancement of social harmony, yet remained colored and saturated by her upbringing and social vision, always ending her novels with religious overtones, selling "the spirit of forgiveness" as a cureall, and should the medicine not work, there is always physical removal: emigration, a very final excision. In her humanitarian effort to ease the suffering of the working poor, Gaskell is truly worthy of our respect and applause, but this does not necessarily provide a real remedy for the existent industrial problems which ailed Victorian society. This make-believe strategy is certainly practiced by many a novelist in the Victorian Era in one way or another, and whether we like it or not, it marks a peculiar way of making sense of the world they inhabited.

\section{North and South}

That Gaskell returned to the themes raised in Mary Barton, perhaps with either more maturity or pragmatism in North and South, provides an opportunity for analyzing what a difference seven years made in the writer's social view. The exact social conditions in England at this period need clearly to be delineated and an explanation thereof may shed some light on the particular thrust of Gaskell's work, in particular North and South.

There are several strands operative in the social tapestry of the 1830's and 40's and, though they form a nexus, were all powerful in their own right. The first and most important was class, practically non-negotiable and ubiquitous. Next comes change, whether political, technological or even religious, and last there is recent history, including events which, though seemingly trivial now, were extremely important then.

\footnotetext{
22 See Eliot's essay “Silly Novels by Lady Novelists” writtenin 1856 for The Westminster Review Vol. 66 old series (October 1856), pp. 442-461.

${ }^{23}$ Thomas Malthus, An Essay on the Principle of Population, Oxford World's Classics, Geoffrey Gilbert (Ed.), (Oxford: Oxford UP, 1993).

${ }^{24}$ Culture and Society, p. 91.
} 
Take, for example, the opening of North and South which, like David Copperfield, is at once idyllic and bucolic. We are presented with the Hales, a clergyman, his wife and daughter Margaret. Despite allusions to Mrs. Hale's upper class family, which are never more than vague and voiced exclusively by their servant Dixon, we are unimpressed by the family's social status and Margaret is a less than prepossessing character with her vocal dislike of "shoppy people", those "who made their fortunes in trade" like the Gormans at Southampton in the novel (Ch. 2, p. 50). Margaret further reveals her class consciousness, clarifying herself by saying, "I like all people whose occupations have to do with land; ...” (Ch. 2, p. 50). Gaskell is sly in her depiction of this character trait, leaving it for the reader to question from which eminence Margaret pontificates. Indeed, who is she to condescend to this class of people? Within the tortuous gradations and nuances of the class system, Margaret is nobody, and that is not up for debate. She maintains her snobbery by virtue of her geographical location, separate from varied society and free to indulge a haughty liberality with "the villagers" upon whom she patronizingly comments: "I think we are far better off, knowing only cottagers and labourers, and people without pretence" (Ch. 2, p. 50).

\section{Margaret's Social Consciousness}

Being so placed enables Margaret to exist in this ersatz hierarchy indefinitely, imagining herself superior and mostly unchallenged. Within this microcosm, however, and unknown to Margaret, forces are at work to eject her from this arcadia. These become suddenly manifest in Mr. Hale's announcement that he will leave both his living and the church. News of this comes directly from him and it intimates that he cannot continue for reasons both spiritual and conscientious. How are we to view this episode, this, it seems, irrelevant opening of the novel ${ }^{25}$ Ambiguity is not equal to the description of this odd event. Is Mr. Hale leaving or being expelled? Helstone, the village in which they live is certainly an Eden, tree girt and fecund and those within it innocent and resistant to change as we see in Chapter 2 with Margaret's refusal of a proposal of marriage with almost undue haste. How has Mr. Hale arrived at his decision to leave the church and was it made for him? His words seem to imply a hasty rewrite of the true situation. To suggest Mr. Hale to be a dissenter is rash, for this word occurs only once in the text and with Dixon's surprising remark: "And master thinking of turning Dissenter at his time of life, ...” (Ch. 5, p. 82) ${ }^{26}$.

Mr. Hale is, therefore, an ex-clergyman, and no amount of latitude granted can place him in any relation to the upper classes. His line is, in fact, tainted by his son Frederick's involvement in a mutiny and his escape to and exile in foreign lands. Margaret's illusory class system is shattered and they are all nobodies, a fact enhanced by the knowledge that an income is now required. The endless euphemisms employed by the English to describe this are risible, for a clergyman does not receive "wages," "salary" or "payment" but a "living." For all the horse trading and speculation as to wealth in Victorian literature it remains the lower orders who receive named remuneration. ${ }^{27}$ The questions of Mr. Hale’s departure from Helstone, his parish, and his sudden need for work are deftly combined in one sentence: "Because there I can earn bread for my family. Because I know no one there, and no one knows Helstone, or can ever talk to me about it” (Ch. 4, p. 70). So anonymity is an aim of this rapid relocation.

\footnotetext{
${ }^{25}$ For a discussion of the seemingly irrelevant but actually deliberate opening of the novel, see Martin Dodsworth's Introduction to North and South, Dorothy Collin (Ed.), pp. 10-17.

${ }^{26}$ The movement was practically dead by 1800. See The Oxford Dictionary of the Christian Church (3rd ed.). Oxford: Oxford UP.

27 Joss Marsh, Word Crimes: Blasphemy,Culture and Literature in Nineteenth-Century England, (Chicago: University of Chicago Press, 1998), p. 216.
} 
How Gaskell inverts the usual tropes of literature in this work is masterful; the ex-clergyman must go to work and what is he to do? Emasculatingly he is to be a private tutor, usually the purview of distressed gentlewomen in literature of this period. Gaskell, writer of a biography of the Brontës, who went out to work as teachers though their father, like Mr. Hale, was a clergyman, here sets things atilt with the father himself deigning to take this position.

Margaret's self regard, faced with these degradations, does not fail her, and she is robust in her adherence to a values system wherein underlings must know their place, in particular the housemaid Dixon, who descants on the family's loss of position to be countered thus by Margaret:

"Dixon! You forget to whom you are speaking... Go! You have made a strange mistake.” (Ch. 5, p. 83)

Mr. Hale himself comments on this same servant:

“Margaret, I sometimes feel as if that woman gave herself airs.”(Ch. 5, p. 86)

This has to be ironic, for Dixon may be deferential in her capacity as an employee, but it is the Hales themselves who are baseless in their assumption of superiority. Margaret's own class consciousness certainly comes from her upbringing, given her parents' own sentiment towards the issue. Any assumption of airs is on their own part.

For all their resilience to the exigencies of the class system in a more cosmopolitan world, the Hales' survival still depends on Mr. Hale finding work. It is in defiance of migratory patterns that the family heads north, abandoning the balmy southern climes for an altogether more rugged landscape. And if the family is, as they so readily express, superior to the likes of Dixon and the trade set, why do they gravitate towards the area where such people are to be found in their most powerful and self assured aspect? It could be argued that this relocation is in direct service of the notional status they have constructed for themselves wherein their true place is blurred and rendered indistinct.

The industrial town they now inhabit has men of means but no standing in the traditional sense of the word. Among these potential benefactors Mr. Hale's scholarship and erudition will be valued-literally as this is his new source of income- -while he himself can avoid the abasement which employment in a school or private home would entail. Margaret, from her first contact with the new environment, has no idea of adjusting her prejudices despite the fact that the very class for whom she feels such distaste now supplies the wherewithal for her continued existence as an unemployed gentlewoman. Where are the gentry, the quality, in Milton? Margaret sets about the task of supplying this need with herself, yet she is sadly behind the times, for the aristocratic axis upon which she imagines the world to revolve has tilted irreversibly. The new rulers of the world are mercantile not noble. Margaret goes to further lengths to reify herself in her status, seeking members of the honest poor to whom she has alluded in their rustic incarnation (Ch. 2, p. 47) and in whose homes she represents some form of "the quality." Between these two points, Margaret has established her position in this new domicile, considering her "haughty" reception of Thornton who has called for her father, her dismissal of his status as her father's employer and her location of a class of people over whom she may play the lady. She has transferred the social construct which is no longer sustainable in her previous abode to a new sphere wherein she may continue to hold a position in society quite unrelated to that she should, in reality, occupy.

The Hales are fakes, snobbish fakes who, as they exploit the industrial bourgeoisie's need for educational credentials to bolster their newly acquired economic power, they simultaneously contrive to bolster their own social place. Their relationship is not even symbiotic, for the Hales are parasitic. But will they be exposed? It should be pointed out that while the self-made men of Milton can defy and, in a way, rewrite the universe of 
social absolutes within which Victorian society operates, Margaret has no such option. She is educated but she is of no consequence. Indeed, Margaret is like Jane Eyre, Lucy Snowe, or Becky Sharp, who can only make the best of what they have, and we should not judge them too hastily and harshly, being free from Victorian class constraints.

\section{Mrs. Thornton and the Exposure of Margaret's Fake Class Superiority}

Exposure of a sort is certainly present in North and South. The dynamic regarding Margaret and Mr. Thornton is naïve when it is set against that of Margaret and Mrs. Thornton, a matriarch and a realist. While her son has respect for Mr. Hale and is sympathetic to their plight, Mrs. Thornton cuts through the class question with considerable insight and brevity of expression: "What business had she, a renegade clergyman's daughter, to turn up her nose at you! I would dress for none of them—a saucy set!” (Ch. 9, p. 117).

Mrs. Thornton's designation is made at this point at a remove, but it comes from a position of considerable authority on the subject of class. As we learn from the story, she comes from nothing, raises her family alone, and has no time for ideas above one's station. Her awareness of the attraction her son feels, first for the Hales as family and later for Margaret, remains antithetical to her understanding of the life these people are living. Mrs. Thornton is respectable, and she cannot be reproached as either a representative of her class or a member of the community. The Hales' careful nurturing of an ambiguous provenance which benefits them in the parvenu ranks of Milton society cuts no ice with Mrs. Thornton, and she certainly makes this clear. As a character she is perhaps Gaskell's greatest creation, a beneficiary of the new industrial class, who occupies a position comparable to the aristocratic hostesses of Thackeray or Austen yet who entertains comfortably within her own milieu, lavishly, in fact, with regard to her table: "But it was one of Mrs. Thornton's rigorous laws of hospitality that of each separate dainty enough should be provided for all the guests to partake, if they felt inclined" (Ch. 20, p. 213). Perhaps the initial image of Mrs. Thornton "mending a large long table cloth of the finest texture” (Ch. 9, p. 116) most eloquently expresses her unaffected combination of extravagance and thrift. ${ }^{28}$

Mrs. Thornton, perversely, represents the reification and solidification of the class system through the clarity with which she identifies the imposture of the Hales. Their perceived superiority complex-in particular with regard to her son whom, she knows, pays their wages - is punctured effectively by her acerbic, yet wholly factual comments on them. Gaskell's genius is to abase the Hales or their affectation at the hands of Mrs. Thornton, a deputy of the lower classes. The Thorntons' conception of the relationship between employers and workers is expounded on at length, and Gaskell is shrewd enough to include Mr. Hale in the ranks of the latter, though with refinements specific to each protagonist.

North and South has often been misinterpreted as a treatise on labor in the North of England or the laborers' mistreatment at the hands of the factory owner, though Mr. Thornton's maturing process with regard to his conception of and attitudes towards the working poor is clearly marked in the book. The novel is, instead, a satirical appraisal of how, in the increasingly unavoidable face of social mobility, certain old world types such as Mr. Hale, a relic of old world pseudo-gentility is displaced, in his case fatally, by his daughter's involvement with and marriage to the new economic nobility, the redemptive power of a parity of status. In other words, Gaskell is a progressive in her understanding of the shift of social gravity.

${ }^{28}$ It was a long standing joke in England that the nouveau riche would drink champagne with abandon while using teabags twice. 
Gaskell dabbled in social reality in Mary Barton, a novel which lost its way and, while both halves are individually effective. It does not cohere in the final analysis, and its earnestness proved unsustainable in the structure of a marketable novel. North and South has yielded to multiple readings; yet it expresses England's progress towards an industrial future in far more accessible terms. The Hales belong to the old world, status obsessed and genteel, yet impoverished, who need the wealth and prosperity of the industrial powerhouse to revivify themselves. The Hales are unaware of this need until they are dispossessed and subsequently sustained by the new rich who still have some lingering attraction to a so called gentleman's education, imparted in this case by one who is, by no measure, a gentleman and who, among the trade he once despised, is accorded disproportionate respect.

It is certainly no accident that Margaret stands alone at the end of the novel, fatherless, motherless, friendless, stripped of those who imparted their prejudices to her and the lowly to whom she gravitated to reify her status. She is free to be reborn, to be taken up by the new economic power at work in the realm and with whom one can forge an entirely new class, with both vigor and heft. Is it any wonder that Mrs. Thornton's opposition, but supposed acquiescence, occupies the novel's last line? In an interval of seven years between the publication of the two novels we have dealt with, Gaskell's social vision had matured into critical realism.

\section{Conclusion}

Are writers then socially conditioned and determined by their class origin, an orthodox Marxist perception of literary production which argues that social being precedes consciousness? This again poses the perennial question raised in the Introduction and our study of Elizabeth Gaskell's social vision seems to suggest that the correspondence is never smooth and straightforward but tortuous and dialectic, a seeming contradiction that bespeaks literary production as at once a mirror and a lamp.

\section{References}

Arnold, M. (1993). Culture and anarchy and other writings (Cambridge texts in the history of political thought). S. Collini, (Ed.). Cambridge: Cambridge University Press.

Barchas, J. (2008). Mrs. Gaskell’s North and South: Austen’s early legacy. Persuasions: The Jane Austen Journal. Chicago, 30, 53-66.

Carlyle, T. (1965). Past and present. R. D. Altick, (Ed.). New York: New York University Press.

Cooney, B. (2011). Violence, terror, and the transformation of genre in Mary Barton. In B. Tredennick (Ed.), Victorian transformations: Genre, nationalism and desire in nineteenth-century literature. Burlington, VT: Ashgate.

Eliot, G. (October 1856). Silly novels by lady novelists. The Westminster Review, 66, 442-461.

Gaskell, E. G. (2006). Mary Barton (Oxford world's classics). (S. Foster, Ed. and intro.). Oxford: Oxford University Press.

Gaskell, E. (1995). North and south (Penguin Classics). Patricia Ingham, (Ed. and intro.). Harmondsworth: Penguin.

Gaskell, E. (1970). North and south. D. Collin, (Ed.); M. Dodsworth, (intro.). Harmondsworth: Penguin.

Gérin, W. (1980). Elizabeth Gaskell: A biography. Oxford: Oxford University Press.

Goldmann, L. (1987). Towards a sociology of the novel. London: Routledge Kegan \& Paul.

Lawrence, D. H. (1985). Study of Thomas Hardy and other essays (The Cambridge edition of the works of D. H. Lawrence). B. Steele, (Ed.). Cambridge: Cambridge University Press.

Malthus, T. (1993). An essay on the principle of population (Oxford world's classics). G. Gilbert, (Ed.). Oxford: Oxford University Press.

Marsh, J. (1998). Word crimes: Blasphemy, culture and literature in nineteenth-century England. Chicago: University of Chicago Press.

O’Neill, P. (2001). A world of deference: Paradoxes of Victorian paternalism in John Ruskin, Charles Dickens, and John Stuart Mill. Baton Rouge: Louisiana State University. 
Tillotson, K. (1956). Novels of the eighteen-forties. Oxford: Clarendon.

Williams, R. (1982). The industrial novels. In Culture and society (pp. 87-109). London: Hogarth.

\section{Biography}

Dr. Chen is professor of literature at the Department of Foreign Languages and Literature and Dean of the International College as well as College of Humanities and Social Sciences, Asia University, Taichung, Taiwan. He was the former President of Taiwan ESP Association and served as TESOL ESP IS Chair of 2013. Dr. Chen obtained his doctoral degree in English at University of Maryland, College Park, in February, 1991, with the support of a Fulbright scholarship and a grant from National Science Council, Taiwan, and has ever since taught at various universities, both national and private, in Taiwan, such as National Sun Yat-sen University, National Kaohsiung First University of Science and Technology, Fooyin University, and Asia University, to name just a few. Aside from his teaching, Dr. Chen has served as chair and dean at five universities. His strength in particular lies in his ability to organize and coordinate academic programs and administrative duties. Dr. Chen's research areas mainly lie in Victorian literature, Post-colonial literature, and English for Specific Purposes. Dr. Chen is also a material writer and has recently published The Joy of Literature (2012) and English for Hospitality and Tourism (2013). He is now writing a book on Victorian novelists, a critical rereading of classic texts. 